\title{
A Christmas Eve Dinner
}

\author{
Dana Reece Baylard \\ Mt. San Jacinto College
}

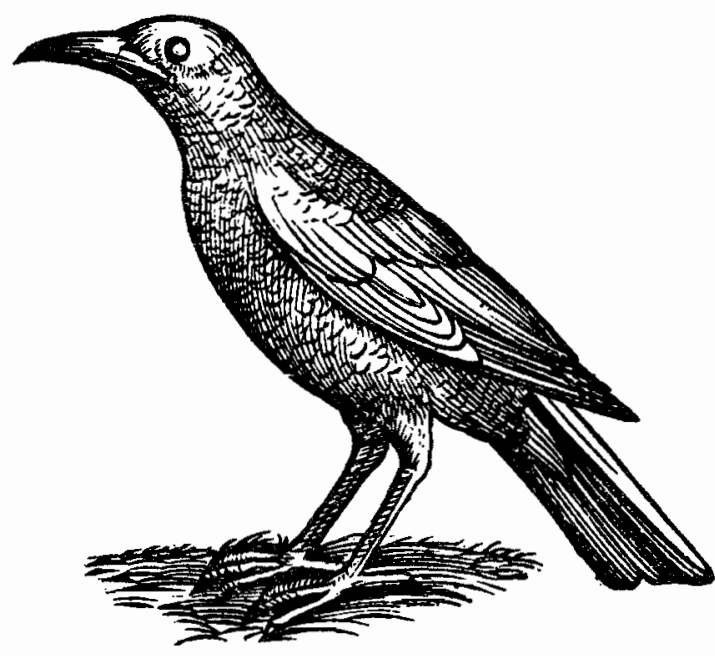

The two women had bought the mountain cottage together, years ago, during a time of idealism and hope for the future. And as the years had passed, the cottage was, at separate times for each of them, the only thing that held life together. Husbands, lovers, children, friends had shared summers amid the towering, sunlit conifers. Many hopes, dreams, and desires had been christened in the embers of the cottage's warm winter holiday fires. And though husbands and lovers sometimes changed, though the children grew up and began their own traditions elsewhere, the women loved and nurtured the cottage as the thing that always remained.

One winter, I was among the friends gathered at the cottage for the winter holidays. I had been there twice before, during summers past, and had enjoyed the caress of the mountain sun as it filtered through the powerful redwoods. The peaceful serenity of the land had so enveloped me that I returned to the city somehow changed, as if I had brought part of that world back with me and had left a part of my city world behind.

Yet this winter, all was not as it should have been at the cottage; those of us who were guests took longer solitary walks than usual, and our eyes often pensively sought the ground when tensions rose. And tensions

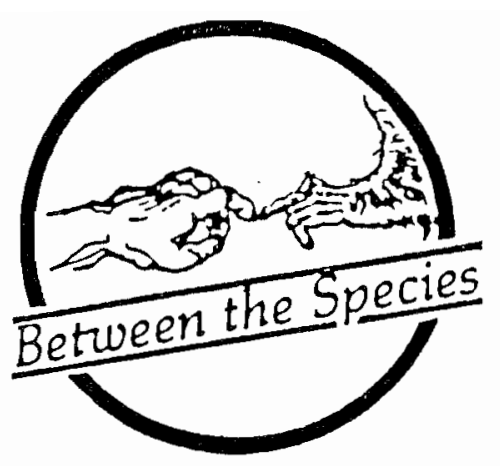

often rose, because in spite of their years of friendship, the two women were not getting along.

They spent long hours murmuring in low voices, their heads down and their eyes looking at either the soft, brown earth or the gentle folds in the hardwood floor. The arguments seemed simple-whether or not a tree should be chopped down, where a new flower garden should be planted-yet they were clearly not simple, or they masked something vastly more labyrinthine, for there was little happiness between them. We guests seldom heard much of these discussions, except for one: the argument about the chickens.

For the past few years, several chickens had roamed about near the barn, scratching, pecking, murmuring in low voices as they searched for food. The original few chickens had been purchased as fuzzy, young chicks for eclectic reasons. Both women knew that the chickens would eat leftovers and provide an excellent source for composting. They both knew that chickens would lay eggs, and they both knew that the chickens would give a warm feel to the mountain cottage, for the rooster now welcomed the sun each morning with a glorious shout, and the fuzzy, yellow chicks wobbled after their mothers and chased each other about. Yet one of the women knew that chickens were also to be eaten. The other knew that they were not.

"The chickens are ours-they should be used as food," argued one woman. "The chickens are our pets,

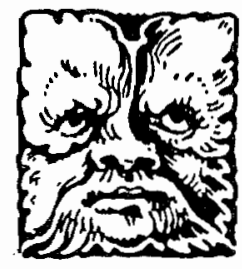

\section{FICTION}


our friends, part of our family," the other woman retorted. The woman who wanted to use the chickens as a food source had grown up on a farm, and chickens had been slaughtered regularly, as were cows and pigs. That's why they were there. After all, buying chicken in the grocery store exhibited hypocritical behavior, she argued, "for it makes little sense to eat what you cannot kill." And the other woman had no argument for that. So it was decided that two large chickens would be slaughtered for Christmas Eve dinner, and that the woman who didn't want to kill the chickens, and who had never killed one or even seen one killed, would be the one to do the job.

How that decision had been made was unclear to the rest of us; possibly, the woman who had never killed a chicken felt the need to prove that she was not hypocritical. Possibly, she was pushed into it by the other woman, who may have never actually killed a chicken herself and was loath to do so. However it was decided, it was decided, and the event was scheduled to take place the following morning just after sunrise.

Most of us awoke the next morning with a feeling of apprehension, but whatever we may have felt, none of us was prepared for what was to follow.

The woman had been instructed to wring the chickens' necks and then cut off their heads with the quick blade of a sharp knife. This was supposedly the most humane way to do the job. Yet what we heard confirmed that this was clearly not the case. Or maybe it was, for how does one ever kill humanely?

None of us watched the woman pursue her victim, but we couldn't avoid hearing her victim's response to her attack, and it became immediately clear that the chickens, however dumb they were supposed to be, knew that something was not right from the moment the woman entered the pen. After the gate scraped the ground and clicked shut, we could hear the chickens mumbling and scurrying about. Wings flapped heavily, and then there was the scream, so like a human scream, high and terrified. After a few slow moments, it grew higher and louder, more desperate; then, in what sounded like a moment of sheer, raw panic, it seemingly diffused into several hoarse shrieks so frightened, mournful, and betrayed that I lost my breath, afraid for the life that was perishing only a few yards away. The wail seemed to hold all of life still until it finally wavered, then ceased. And I felt as if my heart stopped with it.
And then we heard the woman's footsteps running toward the house, and we heard her sorrow as she gulped down agitated sobs. The sight of this woman when she entered the house remains imprinted vividly within my memory. Tears streamed down her frightened face, making steady paths through flecks of blood and dirt. Her chest palpitated heavily, and her old, light grey sweatshirt was speckled with glimmering dots of blood. Her hands were moist and red up to her elbows. She had left the chicken behind somewhere, and it was obvious that she wouldn't kill another one.

I suppose the other woman cleaned and cooked the chicken. That was probably her end of the deal, but we guests didn't see what happened next, for like flecks of oil in water, we floated out in diverse directions, seeking lonely, peaceful mountain trails. While I was hiking, I came upon a shimmering, open field blanketed in green and yellow grasses. I lay on my back, feeling the warmth of the winter sun and listening to the pulse of life surrounding me. I knew that what had happened was somehow very wrong, that it had somehow broken a vein in the pulse of animal and plant life surrounding me. The sound of the chicken's horrible wail roamed through my memory. Many hours passed and the sun shifted deeply in the sky before I was ready to return to the once peaceful cottage.

Dinner preparation was well underway when I returned, and the table was soon set with steaming mashed potatoes, fresh green beans, and a big, colorful green salad in a massive wooden bowl. Fresh bread, red wine, and candles were brought out, and of course, there was the chicken, sitting placidly in the center of the table. The taunt brown skin glimmered in the candle light, and I felt my stomach tighten as I looked at it.

Once we were seated, we all helped ourselves to vegetables, bread and wine, but no one touched the chicken. The woman who had ordered the chicken killed abruptly stood up and carved the chicken deftly, grabbed the other woman's plate, placed a piece of the chicken on it, and then took a piece herself. She then passed it forcefully to the woman on her other side, whose hands shook as she, too, took a small piece, and passed it on. We all took a piece of the sacrifice, and we all ate in silence, making sure to nibble at least a few bites. The body was tough, leathery, hard to chew, but we knew better than to "waste" it. We sensed that there was too much anger and hurt in the room to 
risk upsetting the women even more. They silently ate it, so we did too.

After a long, wordless dinner, I wandered outside in search of fresh, cool air. I felt dizzy and agitated, and my stomach ached painfully. I sat down on the back porch and breathed deeply, trying to still my pounding heart, yet I could feel sweat prickling my forehead in spite of the brisk air. I got up and staggered down the hill toward the barn, then stopped and gazed levelly at the chickens; they were quiet, huddled in a group. I felt a sob work its way out of my throat, and my eyes filled with sudden tears.

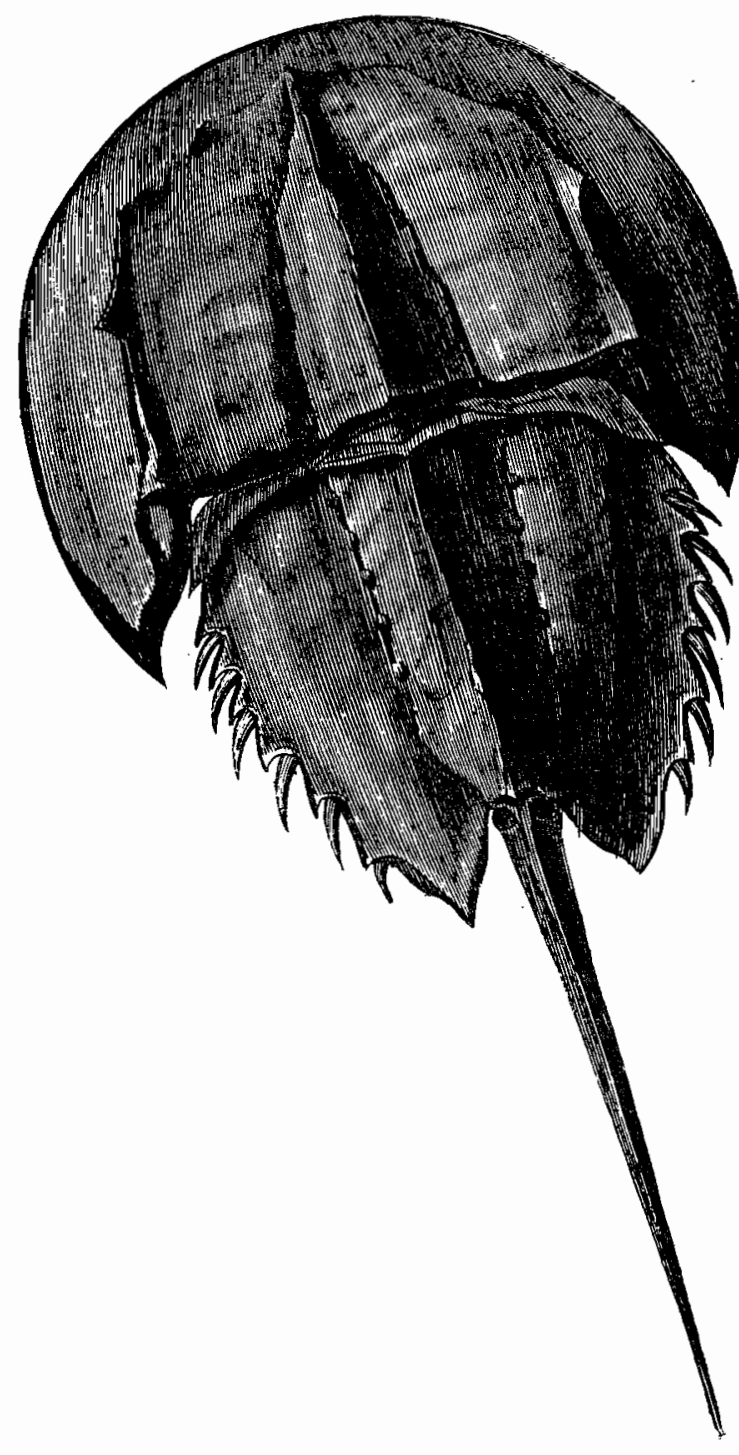

\section{Editorial}

(continued from page 3 )

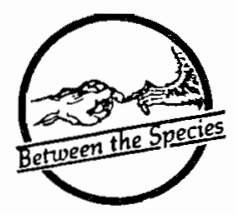

was Gail Crippen who came to the rescue, then between the Summer ' 88 and Fall ' 89 issues it was Shura Chenkin. Shura greatly improved the appearance of the journal, establishing the overall style to which we continue to basically adhere. Getting involved with BTS can mean rather staggering amounts of work. When Shura had to give it up, the "endless" typing of manuscripts was taken up again by Gail Crippen and then by Margaret Wehinger from the Fall ' 90 through Summer '92 issues.

It is principally thanks to the above named individuals that $B T S$ kas survived, even prospered, for the recently mailed Fall '94 issue was, after all, the thirty-sixth issue of the journal! Many others have made important contributions: Jeanne Gocker passing materials between Steve and myself; Mary Starin with the design of the journal's logo; Bev Parish's and Elizabeth Newman's contributions of artwork; the articles and creative writing contributed by all who have written for BTS; the financial support of patrons (especially The Humane Society of the United States) and other contributors and subscribers; BTS's contributing editors; and over the years the members of the board of directors-Ron Lemberg, Rose Lemberg, Pam Ferguson, Eric Mills, and Margaret Stockwell.

Steve and I are immensely grateful to all who have been a part of making $B T S$.

This eighty page Winter/Spring 1994 issue is the first of two double issues that will comprise Volume 10 . With the publication soon of the Summer/Fall '94 issue, ten years of Between the Species will be at an end. With continued luck, Volume 11 Number 1 will be published before spring ' 95 has come and gone. And, who knows? Perhaps Spring '95 will appear in its true season!

John Stockwell 